\title{
Testosterone effect on growth and growth mediators of the GH-IGF-I axis in the liver and epiphyseal growth plate of juvenile rats
}

\section{A Zung ${ }^{1}$, M Phillip ${ }^{2}$, S A Chalew ${ }^{3}$, T Palese ${ }^{4}$, A A Kowarski ${ }^{4}$ and Z Zadik ${ }^{1}$}

\author{
${ }^{1}$ Pediatric Endocrine Unit, Kaplan Medical Center, Affiliated with Hadassah Medical School, \\ The Hebrew University, Jerusalem, Israel \\ ${ }^{2}$ Institute of Pediatric and Adolescent Endocrinology, Schneider Children's Medical Center of Israel, \\ Petah Tikva, Israel \\ ${ }^{3}$ Department of Endocrinology, Children's Hospital and Louisiana State University Medical Center, \\ New Orleans, Louisiana, USA \\ ${ }^{4}$ Division of Pediatric Endocrinology, Department of Pediatrics, University of Maryland School of \\ Medicine, Baltimore, Maryland, USA \\ (Requests for offprints should be addressed to A Zung, Pediatric Endocrine Unit, Kaplan Medical \\ Center, Rehovot, Israel 76100)
}

\begin{abstract}
Several studies have suggested that testosterone may have a direct, GH-independent effect on growth. In order to assess possible mechanism(s) whereby testosterone exerts its growth-promoting effect, we evaluated its effect on growth mediators of the GH-IGF-I axis, in both the liver and the epiphyseal growth plate (EGP). Testosterone was administered to peripubertal rats and the responses of mRNA of GH receptor, IGF-I, IGF-I receptor and IGF-binding proteins-1 and -3 (IGFBP-1 and IGFBP-3) as well as circulating IGF-I were evaluated in two time-related models: over $12 \mathrm{~h}$ after a single injection (short-term study) and 10 days after continuous administration (long-term study). Rats in the short-term study were castrated and were killed 1, 4, 6 and $12 \mathrm{~h}$ post injection. Rats in the long-term study were divided into two groups: castrated vs castrated and hypophysectomized, in order to assess the effect of testosterone in the presence and absence of GH. mRNA levels were determined by RNase protection assay, and serum IGF-I by RIA.

Testosterone enhanced weight gain in the rats treated for 10 days, a change that was similar in the presence or absence of GH. This effect was relatively small, however, by comparison with the
\end{abstract}

total weight gained without testosterone. Testosterone had no effect on hepatic IGF-I mRNA abundance but induced a reduction in circulating IGF-I levels, in both the short- and long-term study. Testosterone had no effect on hepatic GH receptor and IGFBP-3 mRNA levels but resulted in a transient, short-term elevation in IGFBP-1 mRNA levels that was maximal $4 \mathrm{~h}$ post injection.

In the EGP, neither testosterone administration nor hypophysectomy had any effect on IGF-I and IGF-I receptor mRNA levels. However, testosterone increased $\mathrm{GH}$ receptor mRNA abundance after 10 days of continuous administration in hypophysectomized rats only.

These data suggest that the effect of testosterone on growth (as assessed by weight gain) is small and is not mediated by changes in hepatic gene expression of IGF-I, IGF-I receptor, IGFBP-1, IGFBP-3 or circulating IGF-I. At the EGP, the testosterone effect on linear growth is not mediated through changes in mRNA abundance of IGF-I and IGF-I receptor. The small but significant elevation of $\mathrm{GH}$ receptor mRNA levels in hypophysectomized rats may suggest a testosterone-mediated augmentation of a GH effect at the target organ.

Fournal of Molecular Endocrinology (1999) 23, 209-221

\section{INTRODUCTION}

Normal puberty is accompanied by a dramatic increase in the rate of linear growth. The pubertal growth spurt in humans, secondary in magnitude only to the linear growth during the first 2 years of life, is associated with an increase in plasma 
concentrations of sex steroids, insulin-like growth factor-I (IGF-I) and growth hormone (GH) (Thompson et al. 1972, Maurus et al. 1987). While it is well established that gonadal steroids influence body growth (Attie et al. 1990, Keenan et al. 1993), the precise role of testosterone in the pubertal growth spurt in males is not fully understood. Many studies have postulated that testosterone exerts its growth-promoting effect by enhancing the secretory pattern of GH (Martin et al. 1979), which in turn stimulates longitudinal bone growth either via hepatic IGF-I secretion (the somatomedin hypothesis) (Daughaday et al. 1972) or directly at the site of the epiphyseal growth plate (EGP), probably through local production of IGF-I (Isgaard et al. 1988). This indirect effect of testosterone is supported by the observation that testosterone exerts no significant increase in body length in the absence of GH, e.g. in hypophysectomized rats (Simpson et al. 1944, Scow 1952, Jansson et al. 1983).

Several lines of evidence, however, have suggested a GH-independent or synergistic effect (with $\mathrm{GH}$ ) of testosterone on longitudinal bone growth. Growth acceleration has been reported during puberty in children with GH deficiency due to CNS lesions (Attie et al. 1990) or in children with GH insensitivity syndrome (Laron et al. 1980). Similarly, patients with complete GH deficiency due to $\mathrm{GH}$ gene deletion showed growth acceleration in response to treatment with anabolic steroids (Rivarola et al. 1984). These examples demonstrate the capacity of testosterone to stimulate growth, independent of GH or its action. Studies performed in hypophysectomized rats have shown a synergism of testosterone with GH in promoting somatic growth (Simpson et al. 1944, Klindt et al. 1990) or tibial EGP growth (Geschwind \& Li 1955). The mechanism(s) whereby testosterone induces these changes is the subject of the present study. Some clinical data proposed that sex steroids may enhance IGF-I levels (Cara 1989), but recent studies have shown no effect of testosterone on hepatic IGF-I mRNA expression or circulating IGF-I levels in hypophysectomized rats (Phillip et al. 1992, Sahlin et al. 1994). Alternatively, testosterone may modulate the effect of IGF-I either through its binding proteins or its receptor at the target organs. IGF-Ibinding proteins (IGFBPs) regulate the availability of IGF-I and so may modulate the biological activity of IGF-I in vivo (Baxter 1991). Likewise, changes in IGF-I receptor abundance may modulate its growth-promoting effect. IGF-I receptors are present in many target organs including cartilage (Isaksson et al. 1987). Another component of the GH-IGF-I axis that may be affected by testosterone and mediate its growth-promoting effect is GH receptor. GH receptor levels are sensitive to gonadal steroids, but data from previous studies on the nature of this effect are contradictory. Testosterone administration induced an elevation in hepatic $\mathrm{GH}$ receptor mRNA levels in rabbits (Yu et al. 1996), a decrease in GH-binding protein (GHBP) in man (Postel-Vinay et al. 1991) and no change in hepatic $\mathrm{GH}$ receptor $\mathrm{mRNA}$ or circulating GHBP in rats (Carmignac et al. 1993).

The purpose of this study was to investigate simultaneously the direct effect of testosterone on growth and growth mediators along the GH-IGF-I axis in the absence and presence of GH. We evaluated the response to testosterone administration in both liver and EGP, in order to elucidate possible endocrine or autocrine/paracrine mechanisms that account for its growth-promoting effect. Since steroid hormone may induce changes in $\mathrm{mRNA}$ levels within a range of minutes to several hours (Rories \& Spelsberg 1989), we evaluated the effect of testosterone in two experimental timemodels: over $12 \mathrm{~h}$ and 10 days after testosterone administration.

\section{MATERIALS AND METHODS}

\section{Animals}

Short-term study Forty-eight male Sprague-Dawley rats, $80-105 \mathrm{~g}$ body weight (BW), 28 days old (i.e. just prior to onset of normal puberty), were castrated by the supplier (Zivic-Miller, Allison Park, PA, USA) at least 2 days before the study. The animals were weighed on admission and divided into four groups of 12 rats each. Rats in each group were matched by weight and assigned to one of two subgroups, receiving either lipid vehicle (control subgroup) or testosterone (Sigma Chemical Company, St Louis, MO, USA) $100 \mu \mathrm{g} /$ $100 \mathrm{~g} \mathrm{BW}$, by a single s.c. injection (testosterone subgroup). The four groups of animals were killed $1,4,6$ or $12 \mathrm{~h}$ post injection by $\mathrm{CO}_{2}$ inhalation and decapitation.

Long-term study A first group of 18 male SpragueDawley rats was castrated by the supplier at 28 days of age (castrated group). A second group of 24 rats of the same type and age was castrated and hypophysectomized (hypophysectomized group). To ensure an adequate hypophysectomy, these animals were followed up for 7 days, with freely available standard laboratory chow and saltsupplemented water containing $9 \cdot 0 \mathrm{~g} / \mathrm{l} \mathrm{NaCl}$. Only 
animals that demonstrated a weight gain of less than $1 \mathrm{~g} /$ day over the follow-up period were considered to be adequately hypophysectomized.

Rats in both groups were implanted with a $30 \mathrm{~mm}$ long Silastic capsule (Dow-Corning, Midland, MI, USA) s.c. at the sternum area, either at the time of castration (castrated group) or after 7 days of follow-up (hypophysectomized group). Half of the animals received an empty capsule, serving as controls, while the other half received capsules filled with crystalline testosterone. The capsules were incubated in saline for $48 \mathrm{~h}$ prior to implantation to initiate sex steroid diffusion, and to eliminate the elevated steroid levels often observed upon implantation of freshly prepared (unincubated) capsules (Park \& Selmanoff 1993). The testosterone capsules were shown to maintain normal, unstimulated levels of luteinizing hormone in castrated male rats (Damassa et al. 1976). Both castrated and hypophysectomized rats were kept in holding cages for 10 days in diet conditions mentioned above. Six out of 24 hypophysectomized rats were excluded from the study due to inadequate hypophysectomy or initial weight well beyond the average weight of the group. Hence, control and testosterone-treated rats of both castrated and hypophysectomized groups had similar weights at the beginning of the study.

The hypophysectomized animals received replacement therapy consisting of $50 \mu \mathrm{g} / 100 \mathrm{~g} \mathrm{BW}$ hydrocortisone (Upjohn Co., Kalamazoo, MI, USA) and $1 \mu \mathrm{g} / 100 \mathrm{~g}$ BW levothyroxine sodium (LyphoMed, Inc., Rosemont, IL, USA), given as daily s.c. injection over 10 days of the study. The animals were killed on the 11 th day by $\mathrm{CO}_{2}$ inhalation and decapitation.

Livers were removed from all rats, in both the short- and long-term studies, and immediately frozen in liquid nitrogen. Similarly, the EGP of each tibia was carefully removed under a magnifying device and frozen. All samples were stored at $-70{ }^{\circ} \mathrm{C}$ until processing.

Animal protocols were approved by the University of Maryland School of Medicine Institutional Animal Care and Use Committee.

\section{RIA of IGF-I}

Serum IGF-I concentrations were measured by specific RIA (Nichols Institute Diagnostics, San Juan Capistrano, CA, USA). For separating IGF-I from its binding protein, an acid-ethanol precipitation technique was used (Daughaday et al. 1980). The intra- and interassay coefficients of variation were 2 and $13.9 \%$ respectively.

\section{RNA preparation}

Frozen samples of liver were homogenized using a Sybron polytron (Brinkmann, Westbury, NY, USA) in a guanidinium isothiocyanate (GIT) solution (RNAzol, Cinna/Biotecx, Friendswood, TX, USA), followed by phenol/chloroform extraction and 2-propanol precipitation. Total RNA was prepared from the EGP by a method described previously (Heinrichs et al. 1994). Briefly, each frozen EGP sample $(50-100 \mu \mathrm{g})$ was homogenized in GIT/sodium citrate/mercaptoethanol solution. The sample was then digested by Tris- $\mathrm{HCl} /$ proteinase $\mathrm{K}$, extracted with phenol/chloroform and precipitated in sodium acetate/chloroform solution at $-20{ }^{\circ} \mathrm{C}$. After centrifugation, the pellet was resuspended in water and $8 \mathrm{M} \mathrm{LiCl}$, precipitated overnight, and finally suspended in Tris-EDTA.

The RNA concentration was determined by measuring the absorbence at $260 \mathrm{~nm}$. The integrity of the RNA was assessed by visual inspection of the ethidium bromide-stained $28 \mathrm{~S}$ and $18 \mathrm{~S}$ rRNA bands after electrophoresis through $1 \cdot 25 \%$ agarose/ $2 \cdot 2 \mathrm{M}$ formaldehyde gels.

\section{Antisense RNA probes}

$I G F-I$ The rat 376 bp probe encoded part of the A domain, the entire $\mathrm{D}$ and $\mathrm{E}$ domain, and part of the 3 '-untranslated region (UTR) of genomic IGF-I. The probe was linearized with HindIII and gel purified before the synthesis of antisense RNA with T7 RNA polymerase. Upon hybridization with the full-length IGF-I mRNA, this antisense RNA recognizes two alternatively spliced sequences, due to the presence (IGF-I Eb) or absence (IGF-I Ea) of a 52 base insert in the region coding for the $\mathrm{E}$ domain (Lowe et al. 1988).

GH receptor The rat GHR template was linearized with BamHI, gel purified, and transcribed with T7 RNA polymerase to generate a $445 \mathrm{bp}$ antisense RNA probe. This probe produces two protected bands when hybridized with total RNA: a 439 base band corresponding to GHR mRNA, and a 298 base band corresponding to the alternatively spliced mRNA which encodes the GHBP (Mathews et al. 1989).

$I G F-I$ receptor A 265 bp EcoRI-RsaI fragment was isolated from one of the rat IGF-I receptor cDNA clones and subcloned into the plasmid pGEM-3. The resulting construct was linearized with EcoRI and gel purified before the synthesis of antisense RNA with SP6 RNA polymerase. Hybridization of this probe with total RNA resulted in a protected band of 265 bases (Werner et al. 1989). 
TABLE 1. Body weights ( $\mathrm{g} \pm$ S.D.) of castrated and hypophysectomized rats in control and testosterone-treated (test) groups on the first day of the study (first) and 10 days later (last)

\begin{tabular}{|c|c|c|c|c|c|c|}
\hline \multirow[b]{3}{*}{ Control } & \multicolumn{3}{|l|}{ Castrated } & \multicolumn{3}{|c|}{ Hypophysectomized } \\
\hline & First & Last & $P$ value & First & Last & $P$ value \\
\hline & $83 \cdot 9 \pm 4 \cdot 4$ & $170 \cdot 6 \pm 10 \cdot 4$ & $<0 \cdot 001$ & $88 \cdot 6 \pm 4 \cdot 0$ & $91 \cdot 6 \pm 3 \cdot 5$ & NS \\
\hline Test & $81 \cdot 1 \pm 4 \cdot 5$ & $183 \cdot 5 \pm 10 \cdot 4$ & $<0 \cdot 001$ & $91 \cdot 4 \pm 2 \cdot 7$ & $100 \cdot 8 \pm 5 \cdot 5$ & $<0.001$ \\
\hline$P$ value & NS & $0 \cdot 022$ & & NS & $<0.001$ & \\
\hline
\end{tabular}

IGFBP-1 A 203 bp XmaI-AccI fragment derived from a rat IGFBP-1 cDNA was subcloned into the plasmid pGEM-4Z. This construct was then linearized with EcoRI and transcribed with T7 RNA polymerase. On hybridization with total RNA, this probe resulted in a protected band of 203 bp (Phillip et al. 1994).

IGFBP-3 The probe was generated by subcloning an HincII-AluI fragment of the corresponding cDNA into a pGEM-4Z plasmid. After linearization with ACCI, it was transcribed with T7 RNA polymerase (Ricciarelli et al. 1992).

pT7 18S RNA A complementary 18S rRNA probe was used as an internal control to establish the relative amount of RNA in each sample. Upon hybridization with total RNA, the HindIIIlinearized $109 \mathrm{bp}$ template (Ambion Inc., Austin, TX, USA) produces an 80 base band, corresponding to $18 \mathrm{~S}$ rRNA. In order to achieve at least 5 -fold molar excess of the antisense probe over the highly abundant target $18 \mathrm{~S}$ rRNA, a MEGAscript T7 (Ambion Inc.) was used for the transcription reaction.

\section{Solution hybridization/RNase protection assay}

The solution hybridization/RNase protection assay were performed as previously described (Lowe et al. 1988). Briefly, $20 \mu \mathrm{g}$ total RNA were hybridized with 200000 c.p.m. $\left[{ }^{32} \mathrm{P}\right]$ UTP-labeled antisense probes, and simultaneously with $1.4 \mu \mathrm{g}$ p T7 RNA $18 \mathrm{~S}$ probe as an internal control. The hybridization was carried out for $16 \mathrm{~h}$ at $45{ }^{\circ} \mathrm{C}$ in $75 \%$ formamide- $0.4 \mathrm{M} \mathrm{NaCl}$, followed by digestion with $40 \mu \mathrm{g} / \mathrm{ml}$ RNase-A and $2 \mu \mathrm{g} / \mathrm{ml}$ RNase T1. Protected hybrids were precipitated, denatured and electrophoresed through $8 \%$ polyacrylamide-urea gels. Gels were exposed to Kodak X-Omat AR film (Eastman Kodak, Rochester, NY, USA) at $-70{ }^{\circ} \mathrm{C}$ with two intensifying screens. Protected bands on the autoradiograph were scanned using a scanning densitometer (Molecular Dynamics, Sunnyvale, CA, USA). The scanning results were analyzed by ImageQuant software (Molecular Dynamics), and the integrated volume of each band was corrected for the integrated volume of the corresponding $18 \mathrm{~S}$ rRNA band. Each sample was assayed at least twice and the mean of the replicates was used for data analysis.

\section{Statistical analysis}

mRNA levels were expressed as a percentage of the control in each assay. The differences between means of the control and testosterone-treated groups were assessed by Student's $t$-test. Data were analyzed using SigmaStat and SigmaPlot software (Jandel Scientific, San Rafael, CA, USA).

\section{RESULTS}

\section{Changes in animal weights}

Changes in weight were evaluated in the long-term study. Mean weights of the castrated rats, a day after castration and tube implantation, were $83 \cdot 9 \pm 4 \cdot 4$ (s.D.) and $81 \cdot 1 \pm 4 \cdot 5 \mathrm{~g}$ for control and testosterone-treated animals respectively $(P=\mathrm{NS})$. Weights were more than doubled over 10 days of follow-up in both subgroups, but in testosteronetreated animals final weights were significantly higher than weights in the control group $(183 \cdot 5 \pm 10 \cdot 4$ vs $170 \cdot 6 \pm 10 \cdot 4 \mathrm{~g}$ respectively, $P=$ 0.022 ) (Table 1), as well as the percentage change in weight $(126 \cdot 3 \pm 7 \cdot 1$ vs $103 \cdot 3 \pm 6 \cdot 9 \%$ in control group, $P<0 \cdot 001)$.

In the hypophysectomized group, 9 days after hypophysectomy and 2 days after tube implantation, the initial weights were similar in control and testosterone-treated rats. Ten days later, weight change was statistically significant only in testosterone-treated animals $(91.4 \pm 2.7 \mathrm{~g}$ initial weight vs $100 \cdot 8 \pm 5 \cdot 5 \mathrm{~g}$ final weight after 10 days, $P<0 \cdot 001$ ) (Table 1). Similar to the castrated 
animals, mean final weight of hypophysectomized rats treated with testosterone was significantly higher than the corresponding mean weight of the control group $(100 \cdot 8 \pm 5 \cdot 5$ vs $91 \cdot 6 \pm 3 \cdot 5 \mathrm{~g}$ respectively, $P<0 \cdot 001$ ) (Table 1 ) and so was the percentage change in weight gain $(10 \cdot 1 \pm 3 \cdot 8$ vs $3.6 \pm 6.9 \%$ respectively, $P=0 \cdot 024)$.

\section{Serum IGF-I levels}

In the long-term study, serum IGF-I concentrations were markedly reduced in response to hypophysectomy, and were in the range $1-2 \%$ of IGF-I levels measured in pituitary-intact rats. In castrated rats receiving testosterone for 10 days, serum IGF-I concentrations were significantly lower than corresponding levels in the control group $(801 \pm 115$ vs $936 \pm 48 \mathrm{ng} / \mathrm{ml}$ respectively, $P=$ 0.005), whereas no effect of testosterone was noted in the hypophysectomized group. This negative effect of testosterone was already observed after a short exposure to testosterone: in the short-term study, the average serum IGF-I concentration of all testosterone-treated animals combined was significantly lower than corresponding value in controls $(679 \pm 139$ vs $775 \pm 132 \mathrm{ng} / \mathrm{ml}$ respectively, $P=0 \cdot 022)$.

\section{IGF-I mRNA}

No changes were observed in IGF-I mRNA levels in response to short-term exposure to testosterone (up to $12 \mathrm{~h}$ ) in liver or EGP tissues. In the long-term study, the effect of GH deficiency (i.e. hypophysectomy with hydrocortisone and levothyroxine supplements) was assessed in the control hypophysectomized vs control castrated animals. Mean mRNA values in the control castrated rats were defined as 100, with the corresponding S.D. for each transcript. Hepatic IGF-I mRNA levels were reduced 25 -fold in control hypophysectomized rats compared with control castrated rats $(4 \cdot 1 \pm 3 \cdot 2$ vs $100 \cdot 0 \pm 15 \cdot 0$ for IGF-I Ea and $4 \cdot 2 \pm 2 \cdot 0$ vs $100 \cdot 0 \pm 15 \cdot 3$ for IGF-I Eb transcripts respectively, both $P<0.001$ ) (Fig. 1). By contrast, hypophysectomy had no effect on IGF-I mRNA levels in the EGP (Fig. 2).

Testosterone administration for 10 days had no effect on hepatic and EGP IGF-I mRNA levels, either in the absence (hypophysectomized group) or presence (castrated group) of GH (Fig. 3 for liver; Figs 2 and 4 for EGP). As shown in Fig. 2, the overall IGF-I mRNA levels in the EGP were much lower than corresponding levels in the liver, in both intact and hypophysectomized rats.

\section{GH receptor/GHBP mRNA}

In the short-term study, testosterone had no effect on GH receptor or GHBP mRNA levels, either in the liver or in the EGP.

In the long-term study, hypophysectomy (in control hypophysectomized rats) induced a small $(30-40 \%)$ but significant reduction in hepatic mRNA levels compared with the control castrated group, in both $\mathrm{GH}$ receptor $(69 \cdot 7 \pm 27 \cdot 8$ vs $100 \cdot 0 \pm 19 \cdot 3$ respectively, $P=0 \cdot 016)$ and GHBP $(60 \cdot 3 \pm 32 \cdot 2$ vs $100 \cdot 0 \pm 24 \cdot 6$ respectively, $P=0 \cdot 01)$ (Fig. 1). Similar to IGF-I mRNA levels, no changes were observed in GH receptor or GHBP mRNA levels after hypophysectomy in the EGP (Fig. 2). There were no changes in GH receptor and GHBP hepatic mRNA levels after testosterone administration for 10 days, in both castrated and hypophysectomized animals (Fig. 3). Similarly, no changes were observed in both mRNA transcripts in the EGP after testosterone administration in the castrated rats (Figs 4 and 5). In the hypophysectomized group, however, there was a small but significant increase in EGP GH receptor mRNA levels in testosterone-treated rats compared with controls $(141 \cdot 2 \pm 15 \cdot 8$ vs $100 \cdot 0 \pm 13 \cdot 0$ respectively, $P=0.004$ ) (Fig. 5). The increase in GHBP mRNA was not statistically significant $(P=0 \cdot 063)$.

As shown in Fig. 2, mRNA levels of both GH receptor and GHBP in the EGP were remarkably lower than corresponding mRNA levels in the liver.

\section{IGF-I receptor mRNA}

IGF-I receptor mRNA was not detected in liver tissue but only in EGP (Fig. 2). In the short-term study, testosterone had no effect on IGF-I receptor mRNA abundance in the EGP. Neither hypophysectomy (Fig. 2) nor testosterone administration for 10 days (Figs 4 and 5 ) induced any effect on IGF-I receptor mRNA levels in the EGP.

\section{IGFBP-1 and -3 mRNA}

Unlike the absence of short-term effect of testosterone on other mRNA transcripts assessed in this study, hepatic IGFBP-1 mRNA levels were increased by 2 - to 3 -fold in the testosterone-treated group compared with that in the control group in the short-term study (Fig. 6). The change in mRNA levels was highly significant $4 \mathrm{~h}$ post testosterone injection $(265 \cdot 7 \pm 63 \cdot 0$ vs $100 \cdot 0 \pm 68 \cdot 0$ in control, $P<0.001)$ and approached statistical significance $(P=0 \cdot 07)$ at both 1 and $12 \mathrm{~h}$ time-points (Fig. 6). This effect was transient, however, as no change in hepatic IGFBP-1 mRNA levels in response to testosterone was observed in the long-term study, 

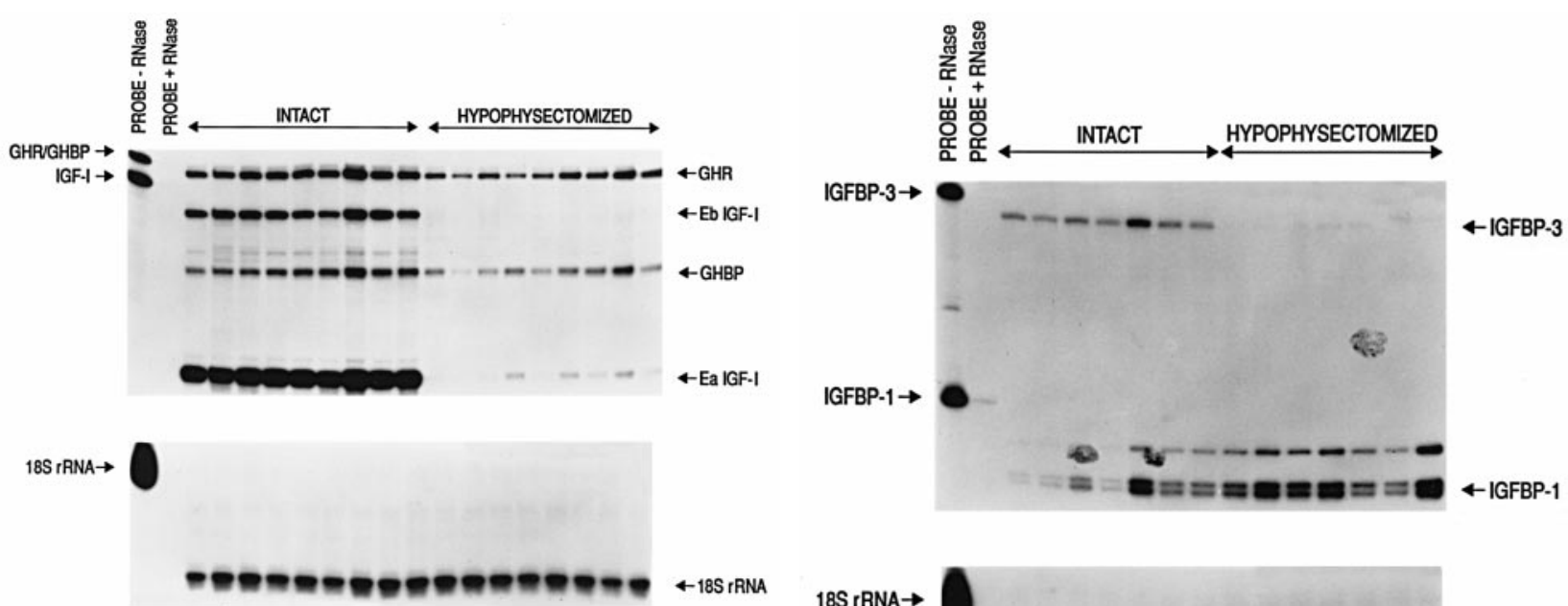

$18 \mathrm{rRNA} \rightarrow$
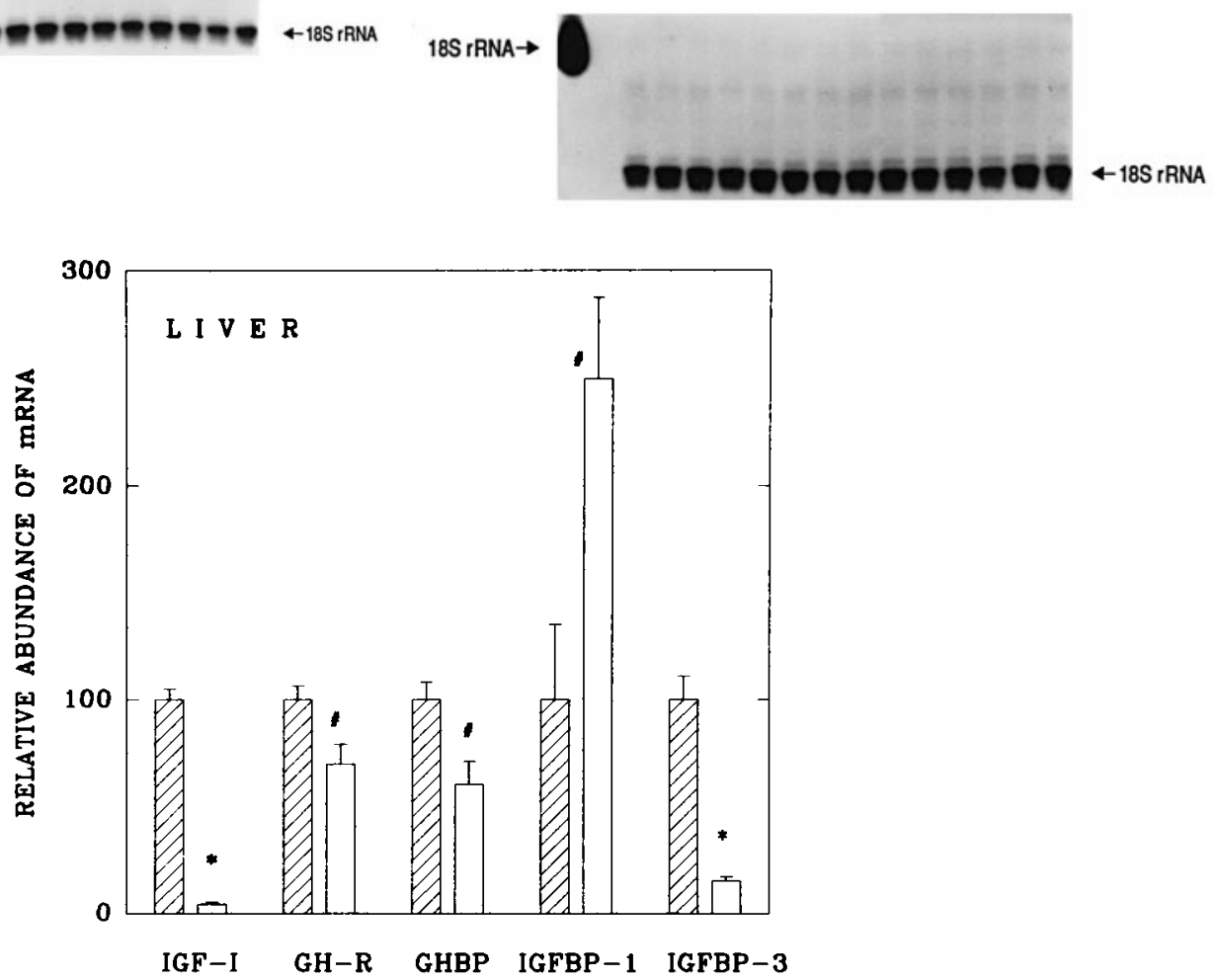

FIGURE 1. RNase protection assay of liver RNA samples in castrated vs castrated and hypophysectomized rats. Twenty micrograms total RNA samples were hybridized with GH receptor (GHR) and IGF-I riboprobes (upper left panel) and IGFBP-1 and IGFBP-3 riboprobes (upper right panel), simultaneously with 18S rRNA which served as an internal control. mRNA samples were obtained after 10 days of follow-up. The arrows to the right indicate the postition of the protected bands. In the upper left panel, these arrows indicate two alternatively spliced IGF-I (Ea and $\mathrm{Eb}$, see Methods) and two alternatively splied GHR bands, corresponding to GHR and GHBP. The arrows to the left indicate the position of the antisense probes, digested with (probe $+\mathrm{RNase}$ ) or without (probe $-\mathrm{RNase)}$ RNases. The effect of hypophysectomy on hepatic mRNA levels of IGF-I, GHR, IGFBP-1 and IGFBP-3 is presented in the lower panel. mRNA levels in castrated, pituitary intact animals (hatched bars) were defined as 100 for each transcript and compared with corresponding levels in hypophysectomised rats (open bars). Although depicted on the same scale, the different transcripts are compared only with their relative controls and not with each other. Each bar represents the mean \pm s.E.M.of nine animals. $* P<0 \cdot 001 ; \# P<0 \cdot 02$. 


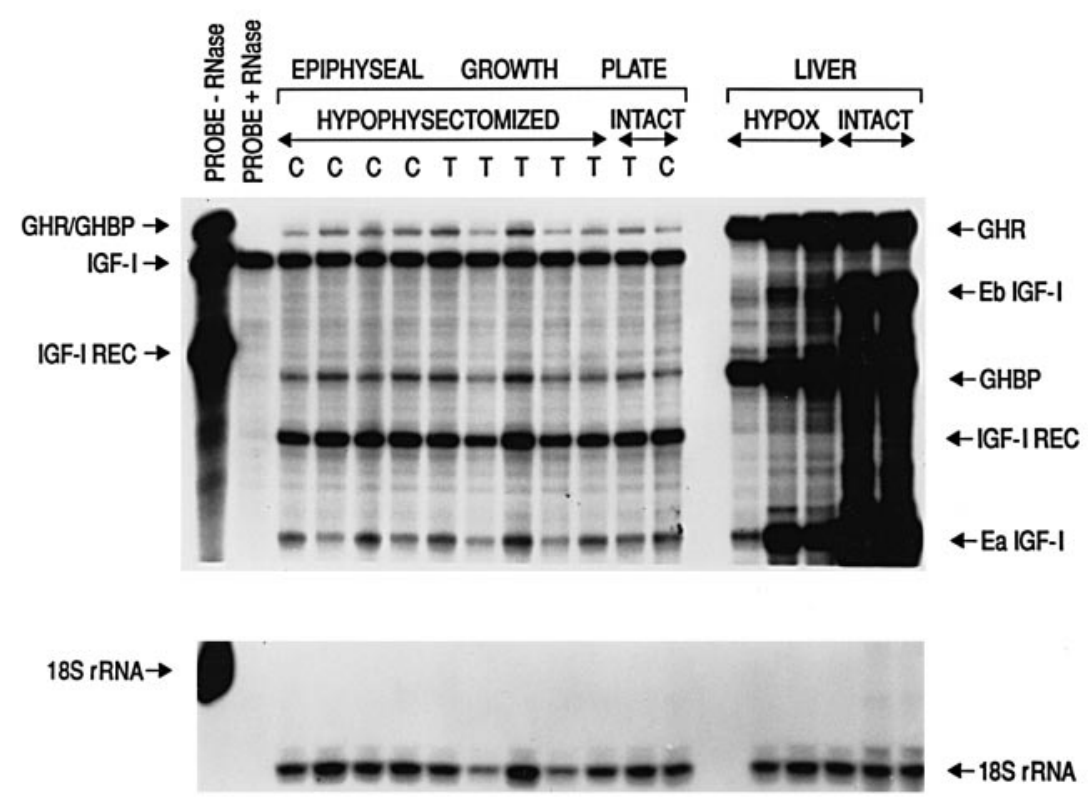

FIGURE 2. Solution hybridization/RNase protection assay showing mRNA protected bands in rat EGP (left side) and liver (right side). The arrows to the right indicate the protected bands of the two alternatively spliced IGF-I mRNAs (IGF-I Ea and Eb), the two alternatively spliced GH receptors $(\mathrm{GH}$ receptor (GHR) and GHBP), the IGF-I receptor and 18S rRNA which served as an internal control. The arrows to the left indicate the position of the different probes digested with (probe $+\mathrm{RNase}$ ) or without (probe - RNase) RNases. Samples were obtained from castrated and castrated and hypophysectomized (hypox) rats. The animals were treated for 10 days with testosterone-containing capsules ( $\mathrm{T}$ ) that were implanted s.c., or with empty capsules (control, C). The effect of testosterone is shown only in the EGP.

in both castrated and hypophysectomized groups (Fig. 3).

Testosterone had no effect on hepatic IGFBP-3 mRNA levels over $12 \mathrm{~h}$ or 10 days post injection, in both castrated and hypophysectomized groups (Figs 3 and 6).

Hypophysectomy resulted in a $6 \cdot 6$-fold decrease in the abundance of hepatic IGFBP-3 mRNA and a diametrically opposed effect $(2 \cdot 5$-fold increase $)$ in hepatic IGFBP-1 mRNA levels (Fig. 1).

IGFBP-1 and -3 mRNA were not assessed in the EGP due to limited amounts of total RNA obtained from this tissue.

\section{DISCUSSION}

Testosterone has a GH-independent effect on growth (presented as weight gain) in juvenile male rats, an effect we found to be relatively small by comparison with the growth-promoting effect of GH. The contribution of testosterone to weight gain was similar in the presence (castrated group) or absence (hypophysectomized group) of $\mathrm{GH}$, and hence cannot be attributed to testosterone-induced GH secretion (Martin et al. 1979) or derived from a synergism between testosterone and GH (Simpson et al. 1944, Klindt et al. 1990). Our results are in agreement with those of Simpson et al. (1944), but in contrast to others, who found that weight gain in response to testosterone was substantially higher in the presence of $\mathrm{GH}$, suggesting that $\mathrm{GH}$ may mediate the effect of testosterone on weight (Scow 1952, Jansson et al. 1983).

While the growth-promoting effect of testosterone has been shown in humans (Attie et al. 1990, Keenan et al. 1993), and supported by observations on its direct effect on rabbit epiphyseal articular chondrocytes (Corvol et al. 1987) and rat tibial EGP width (Ren et al. 1989), the precise mechanism(s) of testosterone action is elusive. We found no change in hepatic IGF-I mRNA levels in response to testosterone administration, either over $12 \mathrm{~h}$ post injection, or after 10 days of continuous exposure to testosterone. As expected, GH deficiency induced a remarkable decrease in hepatic IGF-I mRNA levels 

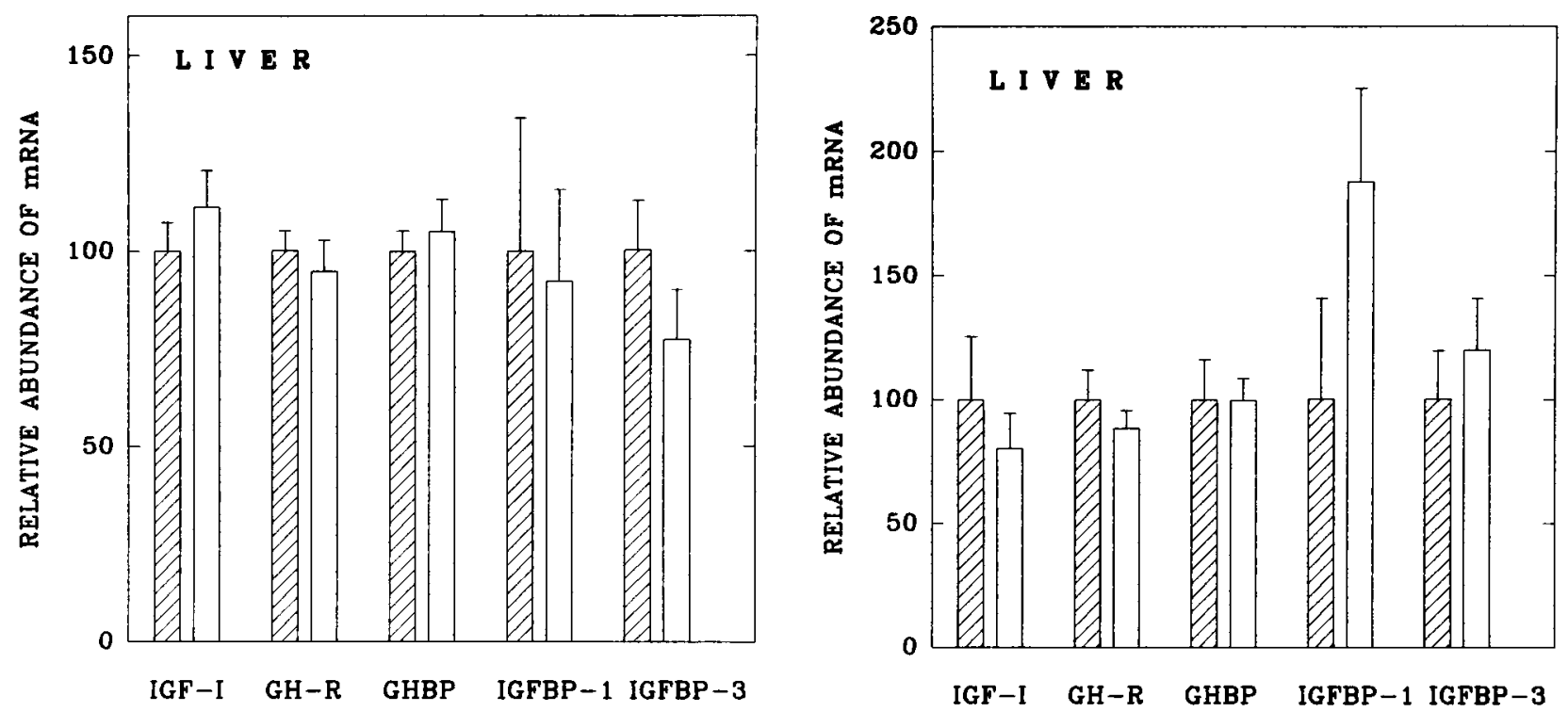

FIGURE 3. Hepatic mRNA levels of IGF-I, GH receptor (GH-R), GHBP and IGFBP-1 and IGFBP-3 in testosterone-treated animals (open bars) vs control groups (hatched bars). Testosterone was administrated by s.c. implanted capsule containing crystalline testosterone for 10 days, either in the presence (castrated rats, left panel) or absence (castrated and hypophysectomized rats, right panel) of GH. mRNA levels of the control groups were defined as 100 for each transcript, and compared with corresponding transcripts in testosterone-treated animals. The different transcripts of testosterone-treated animals are compared only with their controls and not with each other. Each bar represents the mean \pm s.E.M. of nine animals.

(Roberts et al. 1986), which was not affected by testosterone. Even in pituitary-intact animals, however, hepatic IGF-I mRNA levels remained unchanged in response to testosterone, suggesting that testosterone neither stimulated the secretion of GH nor acted synergistically with GH to stimulate hepatic IGF-I transcription. These findings extend a previous study, where no effect of testosterone on hepatic IGF-I mRNA was found in hypophysectomized male rats treated for only 5 days by daily injections of testosterone (Phillip et al. 1992). In this study, however, the effect of testosterone was not examined in pituitary-intact animals. In a different model comprising ovariectomized or hypophysectomized adult female rats (55-60 days old), no effect on hepatic IGF-I mRNA was found after testosterone administration for 7 days (Sahlin et al. 1994). Taken together, it is concluded that testosterone has no effect on hepatic IGF-I mRNA either in male or female rats, in both the presence or absence of GH. By contrast, we found significantly lower levels of circulating IGF-I levels in the testosterone-treated rats in both the short- and long-term studies. No change in circulating IGF-I levels was found in hypophysectomized rats, however, probably due to very low values of IGF-I in this group. In the same line of evidence, previous studies in male rats have shown an enhanced pubertal IGF-I surge 2 weeks after castration, an observation ascribed by Handelsman et al. (1987) to a restraining influence of testosterone on IGF-I production. Similarly, genetically hypogonadal mice and castrated guinea-pigs had an exaggerated pubertal IGF-I surge compared with intact animals (Beaune et al. 1992, Crawford et al. 1993), an effect that was normalized by testosterone administration (Crawford et al. 1993). In contrast to our findings in rats, testosterone administration to hypogonadal (Liu et al. 1987) and normal men (Hobbs et al. 1993), as well as to male adolescents with delayed puberty (Keenan et al. 1993), has been reported to increase circulating levels of IGF-I. The change in IGF-I concentration was associated with, and probably could be attributed to, an elevation in $\mathrm{GH}$ secretion (Albiston \& Herington 1992), rather than to a direct effect of testosterone. Though speculative, the reduction in serum IGF-I levels in rats may mediate the stimulating effect of testosterone on GH secretion, since GH and IGF-I maintain negative feedback. It is conceivable that the negative effect of testosterone on circulating IGF-I levels in our study is post-transcriptional, as it was not preceded by a decrease in hepatic IGF-I mRNA.

In order to further elucidate the regulatory mechanism whereby testosterone reduced serum IGF-I levels, we simultaneously evaluated the effect 


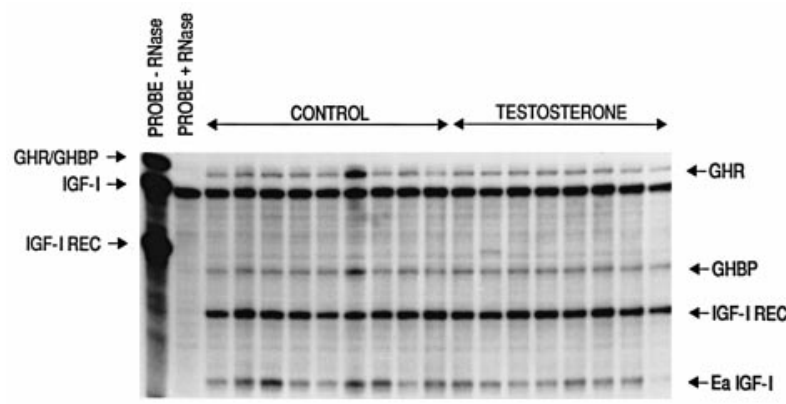

$18 \mathrm{r} r \mathrm{RNA} \rightarrow$

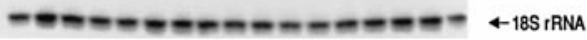

FIGURE 4. Solution hybridization/RNase protection assay of EGP RNA samples from castrated rats treated for 10 days with s.c. implanted capsules which were empty (control) or filled with crystalline testosterone. Twenty micrograms total RNA samples were hybridized with a ${ }^{32} \mathrm{P}$-labeled IGF-I, GH receptor (GHR) and IGF-I receptor (IGF-I REC) rat riboprobes, simultaneously with $18 \mathrm{~S}$ rRNA which served as an internal control. The arrows to the right indicate the position of protected bands, including two alternatively spliced GH receptor mRNA bands (GHR and GHBP). Only one of the two alternatively spliced IGF-I mRNAs is presented (i.e. IGF-I Ea), as the other mRNA band (i.e. IGF-I Eb) had too low a signal. The arrows to the left indicate the position of the different probes digested with (probe + RNase) or without (probe - RNase)

RNases. Each lane represents a single animal.

of testosterone on hepatic IGFBP-1 and -3. The liver is a major site of synthesis of both binding proteins (Albiston \& Herington 1992), and IGFBP-3 is the predominant binding protein in rat and human sera. We found no effect of testosterone on hepatic mRNA levels of both binding proteins in the long-term study. Further study at the protein level is required, however, as circulating levels of IGFBP-3 would appear not to be primarily regulated at the level of mRNA abundance (Donovan et al. 1989). In the short-term study, testosterone had no effect on hepatic IGFBP-3 mRNA abundance, but induced a more than 2-fold increase in IGFBP-1 levels, a change that was most prominent $4 \mathrm{~h}$ post injection. This transient effect of testosterone was not observed in the long-term study, and may reflect the supraphysiological serum levels of testosterone obtained after a single injection. Serum testosterone levels peaked $30 \mathrm{~min}$ post injection, and after $2 \mathrm{~h}$ they were still 10 -fold higher than reported levels gained by the implanted tube (data not shown) (Damassa et al. 1976). As previously reported (Blum \& Ranke 1990), GH deficiency increased IGFBP-1 and decreased IGFBP-3 hepatic mRNA.

Another component in the GH-IGF-I axis that may mediate the testosterone-promoting effect on growth is GH receptor. Testosterone administration had no effect on hepatic mRNA levels of the two alternatively spliced transcripts of GH receptor and GHBP, in both the short- and long-term studies. This is in accord with Carmignac et al. (1993), who found that testosterone administration to $\mathrm{GH}$ deficient rats had no effect on GHBP or GH receptor, nor did it affect their up-regulation by GH. Furthermore, they found that testosterone had no effect on hepatic mRNA levels of both transcripts, in both the presence or absence of GH (Carmignac et al. 1993). While examining the effect of $\mathrm{GH}$ deficiency on hepatic GH receptor and GHBP mRNA levels, we found a significant reduction in the abundance of both transcripts in hypophysectomized rats. The reported effect of hypophysectomy on liver GH receptor expression is somewhat contradictory. In male rats, no change (Mathews et al. 1989, Domene et al. 1993) or even an increase (Frick et al. 1990) in hepatic GH receptor mRNA was found after hypophysectomy. On the other hand, in female rats, hypophysectomy reduced GH receptor and GHBP mRNA levels by 30-35\% (Maiter et al. 1992), very similar to the range of reduction found in the present study. The diversity in methods used in the previous studies may account for the different results. Unlike others, we used internal controls in each assay, which we found helpful in discriminating small changes in mRNA abundance. Alternatively, the reduction in GH receptor/GHBP mRNA may reflect a reduction in a subpopulation of hepatic GH receptor transcripts containing a specific $5^{\prime}$-UTR sequence, termed GHR1 (Baumbach \& Bingham 1995). Hypophysectomy vastly reduced GHR1 mRNA expression (Baumbach \& Bingham 1995) while $\mathrm{GH}$ administration increased its abundance in GH-deficient dwarf rats (Gabrielsson et al. 1995). This subclass of $\mathrm{GH}$ receptor/GHBP mRNA is expressed only in the liver (which may account for the absence of change of GH receptor mRNA in EGP) and is far more abundant in females, which may explain the results in female rats (Maiter et al. 1992). Although the determination of this subclass of $\mathrm{GH}$ receptor transcript requires specific probes, it is possible to observe some reduction in GH receptor/GHBP mRNA levels by using a probe directed against the coding sequence. The effect of hypophysectomy on $\mathrm{GH}$ receptor/GHBP mRNA may be augmented in our study, where a selection of only severely GH-deficient rats was made by a week-long follow-up of weight gain. Further 

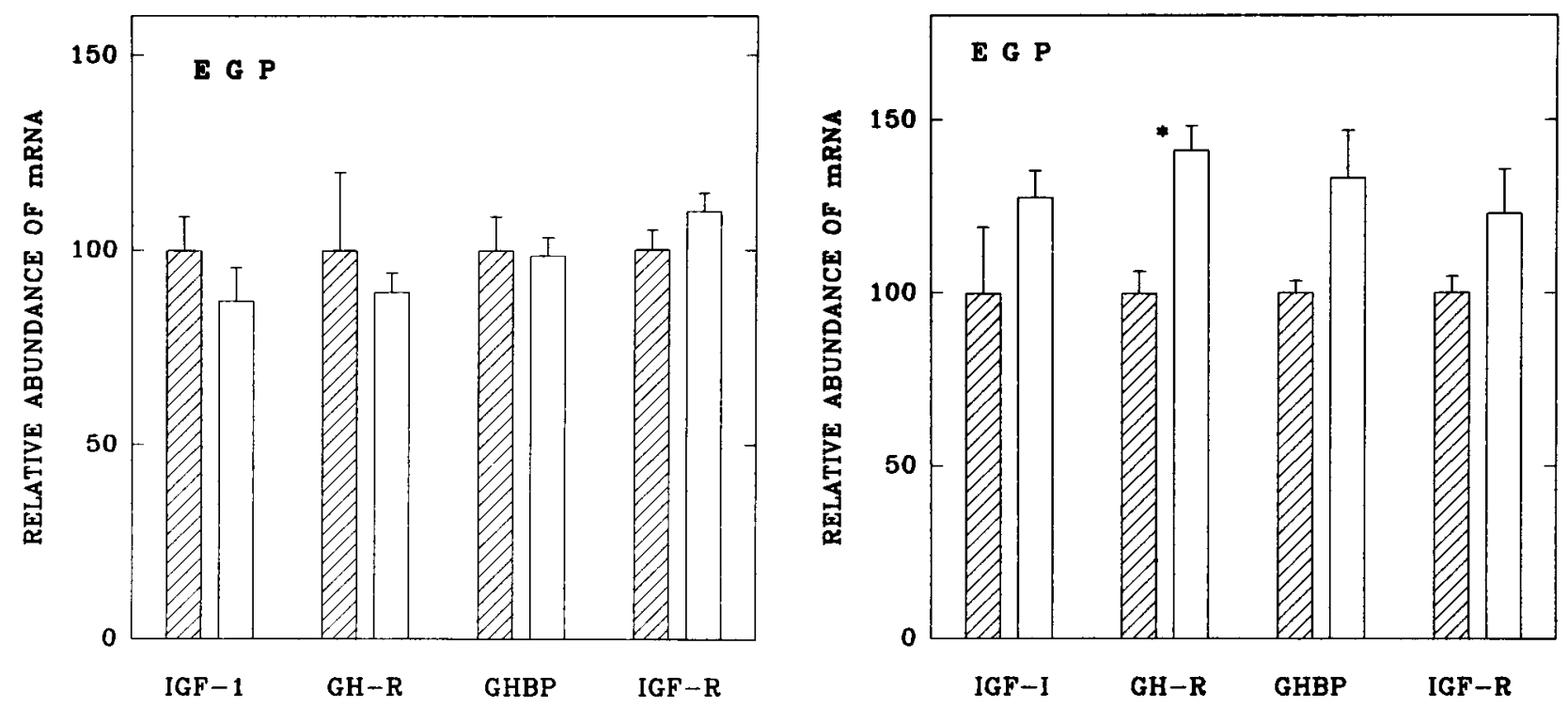

FIGURE 5. EGP mRNA levels of IGF-I, GH receptor (GH-R), GHBP and IGF-I receptor (IGF-R) in castrated, pituitary-intact rats (left panel) and castrated and hypophysectomized rats (right panel). The mRNA levels in control rats (hatched bars) are compared with corresponding mRNA levels in animals treated with testosterone administered by s.c.implanted capsules for 10 days (open bars). mRNA levels of control groups were defined as 100 . The different transcripts of testosterone-treated animals are compared only with their controls and not with each other. Each bar represents the mean \pm s.E.M. of five or six animals. $* P=0 \cdot 004$.

demonstration of this accurate selection comes from the measured serum IGF-I levels, reaching only $1-2 \%$ compared with those in pituitary-intact animals.

While the liver is the main source of growth mediators along the GH-IGF-I axis, EGP is considered the target organ for these mediators. Indeed, the action of IGF-I and GH in promoting long-bone growth is thought to be due to stimulation of EGP chondrocytes proliferation and/or hypertrophy. Although traditionally the GH effect on linear growth was thought to be mediated through the endocrine effect of circulating IGF-I (the somatomedin hypothesis) (Daughaday et al. 1972), several studies have suggested that GH stimulates local production of IGF-I at the EGP, which in turn regulates bone growth by an autocrine/paracrine mechanism (Isgaard et al. 1988). We examined the hypothesis that testosterone enhances growth via local production of IGF-I at the EGP. We also examined the hypothesis that testosterone induces bone growth by affecting the abundance of receptors for GH or IGF-I, rendering the target tissue more sensitive to their effect.

We found no change in EGP mRNA levels of both IGF-I and its receptor, either over $12 \mathrm{~h}$ or after 10 days of exposure to testosterone. In a previous study, five daily injections to a small group of hypophysectomized rats similarly yielded no effect on mRNA of IGF-I and its receptor at the EGP (Phillip et al. 1992). The high level of IGF-I receptor mRNA in EGP compared with liver expression emphasizes the important role of IGF-I in bone growth, as has been previously suggested (Guler et al. 1988). By contrast, IGF-I mRNA in the EGP was very low compared with corresponding levels in the liver. A qualitatively similar ratio of IGF-I protein between liver and cartilage in male rats was found by D'Ercole et al. (1984). Unlike its negative effect in the liver, hypophysectomy induced no change in mRNA levels of both IGF-I and IGF-I receptor at the EGP. This novel observation is supported by a previous report, where extractable IGF-I concentrations in different rat tissues were examined. In response to hypophysectomy, a significant reduction in liver IGF-I concentration was found, while IGF-I levels in the sternum cartilage remained unchanged (D'Ercole et al. 1984). It is conceivable that IGF-I is differentially regulated in a tissue-specific pattern, at both the mRNA and the protein level.

The only growth mediator we found to be regulated in the EGP by testosterone was GH receptor. GH receptor mRNA was mildly but significantly increased in response to testosterone administration for 10 days in the hypophysectomized rats only. A similar but quantitatively smaller effect was observed in male castrated rabbits, where 

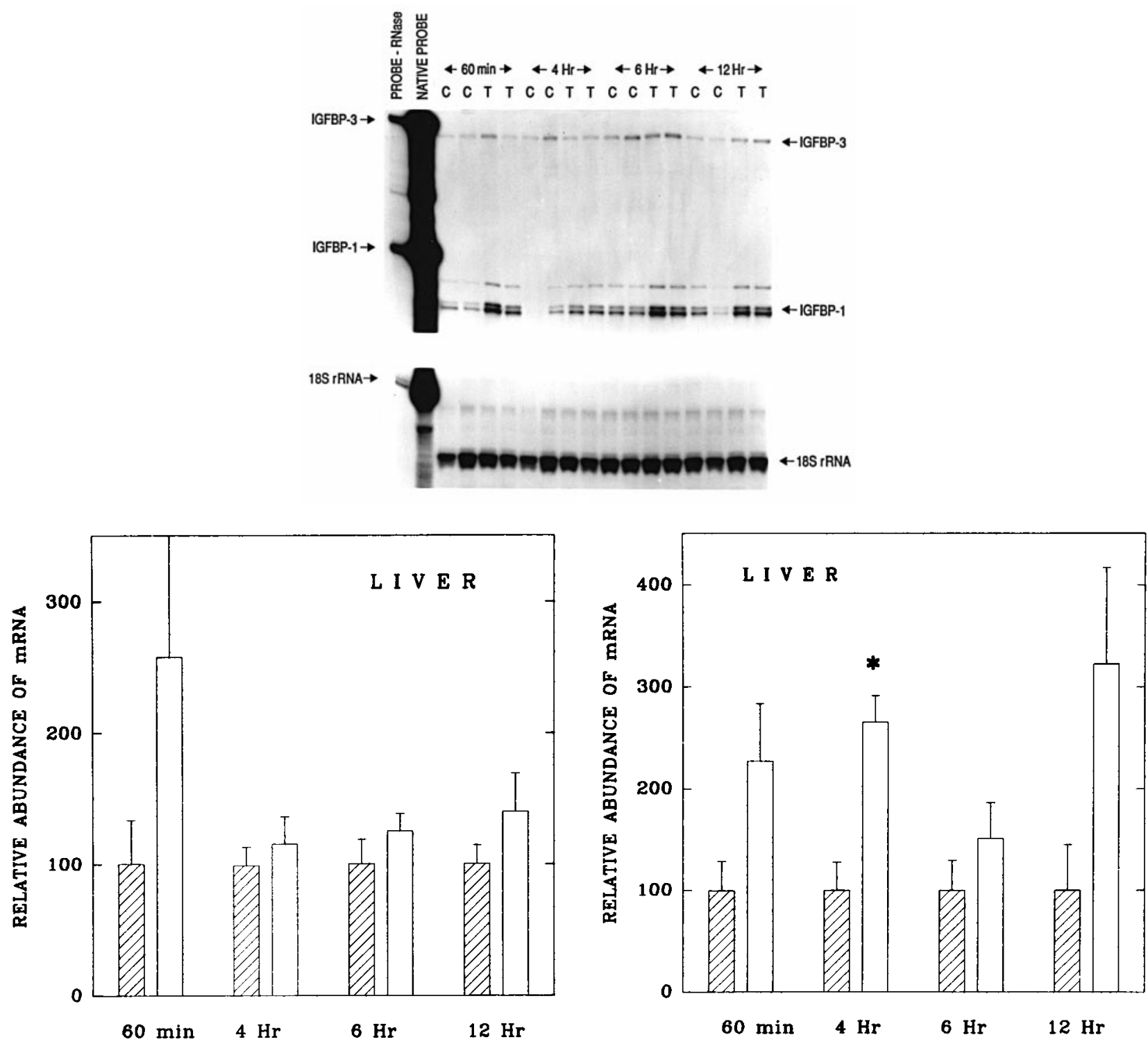

FIGURE 6. Solution hybridization/RNase protection assay showing protected bands of three simultaneously expressed mRNAs in liver: IGFBP-1 and IGFBP-3 together with 18S rRNA which served as an internal control (upper panel). Twenty micrograms total hepatic RNA samples, obtained from castrated rats $1,4,6$ and $12 \mathrm{~h}$ after a single injection of either testosterone (T) $(100 \mu \mathrm{g} / 100 \mathrm{~g} \mathrm{BW})$ or lipid vehicle (control, C) were hybridized with ${ }^{32} \mathrm{P}$-labeled rat riboprobes. Each lane represents a single animal. The arrows to the right indicate the position of the protected bands. The arrows to the left indicate the position of the antisense RNA probes diluted 1:100 (native probe) or diluted 1:200 without RNases (probe - RNase). Lower panels show hepatic mRNA levels of IGFBP-1 (lower right) and IGFBP-3 (lower left) in the experiment described in the upper panel legend. mRNA levels of testosterone-treated rats (open bars) were compared with levels in the control group (hatched bars) defined as 100. Each bar represents the mean \pm s.E.M. of six animals. ${ }^{*} P=0 \cdot 001$ vs control.

continuous testosterone administration over 21 days induced a $28 \%$ increase in $\mathrm{GH}$ receptor mRNA levels at the EGP (Yu et al. 1996). In the castrated group, where no effect of testosterone was observed, it is possible that the presence of $\mathrm{GH}$ counteracts the stimulating effect of testosterone on $\mathrm{GH}$ receptor mRNA levels. Testosterone-related upregulation of $\mathrm{GH}$ receptor mRNA may reflect an indirect mechanism for bone growth through augmentation of the GH effect at the EGP. Unlike 
the negative effect hypophysectomy had on $\mathrm{GH}$ receptor mRNA in the liver, no change in GH receptor/GHBP mRNA level was detected in the EGP in response to hypophysectomy.

In summary, we found that testosterone induced a small increase in weight gain, that was $\mathrm{GH}$ independent. The growth-promoting effect of testosterone is not mediated by stimulating hepatic IGF-I expression. Instead, testosterone had a negative, post-transcriptional effect on circulating IGF-I. Similarly, testosterone had no effect on hepatic GH receptor and IGFBP-3 mRNA levels but induced a transient, short-term elevation in hepatic IGFBP-1 mRNA. In the EGP, testosterone had no effect on gene expression of IGF-I and its receptor, but induced an elevation in $\mathrm{GH}$ receptor gene expression in the absence of GH. Further study is required to elucidate the importance to bone growth of the testosterone effect on GH receptor mRNA.

\section{ACKNOWLEDGEMENTS}

This work was supported in part by a fellowship grant from the Genentech Foundation for Growth and Development and an Israel Ministry of Health Grant (Chief Scientist's Office) (to A Z).

\section{REFERENCES}

Albiston AL \& Herington AC 1992 Tissue distribution and regulation of insulin-like growth factor (IGF)-binding protein-3 messenger ribonucleic acid (mRNA) in the rat: comparison with IGF-I mRNA expression. Endocrinology $130497-502$.

Attie KM, Ramirez NR, Conte FA, Kaplan SL \& Grumbach MM 1990 The pubertal growth spurt in eight patients with true precocious puberty and growth hormone deficiency: evidence for a direct role of sex steroids. Fournal of Clinical Endocrinology and Metabolism 71 975-983.

Baumbach WR \& Bingham B 1995 One class of growth hormone $(\mathrm{GH})$ receptor and binding protein messenger ribonucleic acid in rat liver, GHR1, is sexually dismorphic and regulated by GH. Endocrinology 136 749-760.

Baxter RC 1991 Insulin-like growth factor (IGF) binding proteins: the role of serum IGFBPs in regulating IGF availability. Acta Paediatrica Scandinavica 327 107-114.

Beaune B, Fellmann N, Delaitre M \& Coudert J 1992 Interrelationships between plasma insulin-like growth factor-I (IGF-I) concentrations and plasma sex hormone levels in growing male guinea-pigs. Fournal of Developmental Physiology 17 189-194.

Blum WF \& Ranke MB 1990 Insulin-like growth factor binding proteins (IGFBPs) with special reference to IGFBP-3. Acta Paediatrica Scandinavica 367 (Suppl) 55-62.

Cara JF, Burstein S, Cuttler L, Moll GW \& Rosenfield RL 1989 Growth hormone deficiency impedes the rise in plasma insulin-like growth factor I levels associated with precocious puberty. Fournal of Pediatrics 115 64-68.
Carmignac DF, Gabrielsson BG \& Robinson ICAF 1993 Growth hormone binding protein in the rat: effects of gonadal steroids. Endocrinology 133 2445-2452.

Corvol MT, Carrascosa A, Tsagris L, Blanchard O \& Rappaport R 1987 Evidence for a direct in vitro action of sex steroids on rabbit cartilage cells during skeletal growth: influence of age and sex. Endocrinology 120 1422-1429.

Crawford BA, Singh J, Simpson JM \& Handelsman DJ 1993 Androgen regulation of circulating insulin-like growth factor-I during puberty in male hypogonadal mice. Fournal of Endocrinology 139 57-65.

Damassa DA, Kobashigawa D, Smith ER \& Davidson JM 1976 Negative feedback control of LH by testosterone: a quantitative study in male rats. Endocrinology 99 736-742.

Daughaday WH, Hall K, Raben MS, Salmon WD Jr, Van den Brande JL \& Van Wyk JJ 1972 Somatomedin proposed designation for sulphation factor. Nature 235107.

Daughaday WH, Mariz IK \& Blethen SL 1980 Inhibition of access of basic somatomedin to membrane receptors and immunobinding sites. A comparison of radioreceptor and radioimmunological somatomedin in native and acid ethanol extracted serum. Fournal of Clinical Endocrinology and Metabolism 51 781-788.

D'Ercole AJ, Stiles AD \& Underwood LE 1984 Tissue concentrations of somatomedin C: further evidence for multiple sites of synthesis and paracrine or autocrine mechanisms of action. Proceedings of the National Academy of Sciences of the USA 81 935-939.

Domene H, Kirshnamurthu K, Eshet R, Gilad I, Laron Z, Koch I, Stannard B, Cassorla F, Roberts CT Jr \& LeRoith D 1993 Growth hormone $(\mathrm{GH})$ stimulates insulin-like growth factor I (IGF-I) and IGF-I-binding protein-3, but not $\mathrm{GH}$ receptor gene expression in livers of juvenile rats. Endocrinology 133 675-682.

Donovan SM, Oh Y, Pham H \& Rosenfeld RG 1989 Ontogeny of serum insulin-like growth factor binding proteins in the rat. Endocrinology 125 2621-2627.

Frick GP, Leonard JL \& Goodman HM 1990 Effect of hypophysectomy on growth hormone receptor gene expression in rat tissues. Endocrinology 126 3076-3082.

Gabrielsson BG, Carmignac DF, Flavell DM \& Robinson ICAF 1995 Steroid regulation of growth hormone (GH) receptor and $\mathrm{GH}$-binding protein messenger ribonucleic acids in the rat. Endocrinology 136 209-217.

Geschwind II \& Li CH 1955 The tibia test for growth hormone. In International Symposium on the Hypophyseal Growth Hormone, Nature and Actions, pp 28-53. Eds RW Smith Jr, OH Gaebler \& CNH Long. New York: McGraw-Hill Book Co. Inc.

Guler HP, Zapf J, Scheiwiller E \& Froesch ER 1988 Recombinant human insulin-like growth factor I stimulates growth and has distinct effects on organ size in hypophysectomized rats. Proceedings of the National Academy of Sciences of the USA 85 4889-4893.

Handelsman DJ, Spaliviero JA, Scott CD \& Baxter RC 1987 Hormonal regulation of the peripubertal surge of insulin-like growth factor-I in the rat. Endocrinology 120 491-496.

Heinrichs C, Yanovski JA, Roth AH, Yu YM, Domene HM, Yano K, Cutler GB Jr \& Baron J 1994 Dexamethasone increases growth hormone receptor messenger ribonucleic acid levels in liver and growth plate. Endocrinology 135 1113-1118.

Hobbs CJ, Plymate SR, Rosen CJ \& Adler RA 1993 Testosterone administration increases insulin-like growth factor I levels in normal men. Fournal of Clinical Endocrinology and Metabolism 77 776-779. 
Isaksson OGP, Lindahl A, Nilsson A \& Isgaard J 1987 Mechanism of the stimulatory effect of growth hormone on longitudinal bone growth. Endocrine Review 8 426-438

Isgaard J, Moller C, Isaksson OGP, Nilsson A, Mathews LS \& Norstedt G 1988 Regulation of insulin-like growth factor messenger ribonucleic acid in rat growth plate by growth hormone. Endocrinology 122 1515-1520.

Jansson JO, Eden S \& Isaksson O 1983 Sites of action of testosterone and estradiol on longitudinal bone growth. American Fournal of Physiology 244 E135-E140.

Keenan BS, Richards GE, Ponder SW, Dallas JS, Nagamani M \& Smith ER 1993 Androgen-stimulated pubertal growth: the effects of testosterone and dihydrotestosterone on growth hormone and insulin-like growth factor I in the treatment of short stature and delayed puberty. Fournal of Clinical Endocrinology and Metabolism 76 996-1001.

Klindt J, Ford JJ \& MacDonald GJ 1990 Synergism of testosterone propionate with growth hormone in promoting growth of hypophysectomized rats: effect of sexual differentiation. Fournal of Endocrinology 127 249-256.

Laron Z, Sarel R \& Pertzelan A 1980 Puberty in Laron type dwarfism. European Fournal of Pediatrics 134 79-83.

Liu L, Merriam GR \& Sherins RJ 1987 Chronic sex steroid exposure increases mean plasma growth hormone concentration and pulse amplitude in men with isolated hypogonadotropic hypogonadism. Fournal of Clinical Endocrinology and Metabolism 64 651-656.

Lowe WL Jr, Lasky SR, LeRoith D \& Roberts CT Jr 1988 Distribution and regulation of rat insulin-like growth factor I messenger ribonucleic acids encoding alternative carboxyterminal E-peptides: evidence for differential processing and regulation in liver. Molecular Endocrinology 2 $528-535$.

Maiter D, Walker JL, Adam E, Moats-Staats B, Mulumba N, Ketelslegers JM \& Underwood LE 1992 Differential regulation by growth hormone $(\mathrm{GH})$ of insulin-like growth factor I and GH receptor/binding protein gene expression in rat liver. Endocrinology 130 3257-3264.

Martin LG, Grossman MS, Connor TB, Levitsky LL, Clark JW \& Carmitta FD 1979 Effects of androgen on growth hormone secretion and growth in boys with short stature. Acta Endocrinologica 91 201-212.

Mathews LS, Enberg B \& Norstedt G 1989 Regulation of rat growth hormone receptor gene expression. Fournal of Biological Chemistry 264 9905-9910.

Maurus N, Blizzard RM, Link K, Johnson ML, Rogol AD \& Veldhuis JD 1987 Augmentation of growth hormone secretion during puberty: evidence for a pulse amplitude-modulated phenomenon. Fournal of Clinical Endocrinology and Metabolism 64 596-601.

Park S-K \& Selmanoff M 1993 Hyperprolactinemia suppresses the luteinizing hormone response to $N$-methyl-D-aspartate, epinephrine, and neuropeptide-Y in male rats. Endocrinology 133 2091-2097.

Phillip M, Palese T, Hernandez ER, Roberts CT Jr, LeRoith D \& Kowarski AA 1992 Effect of testosterone on insulin-like growth factor-I (IGF-I) and IGF-I receptor gene expression in the hypophysectomized rat. Endocrinology 130 2865-2870.

Phillip M, Werner H, Palese T, Kowarski AA, Stannard B, Bach LA, LeRoith D \& Roberts CT Jr 1994 Differential accumulation of insulin-like growth factor-I in kidneys of pre- and postpubertal streptozotocin-diabetic rats. Fournal of Molecular Endocrinology 12 215-224.

Postel-Vinay MC, Tar A, Hocquette JF, Clot JP, Fontoura M, Brauner R \& Rappaport R 1991 Human plasma growth hormone $(\mathrm{GH})$-binding proteins are regulated by $\mathrm{GH}$ and testosterone. Fournal of Clinical Endocrinology and Metabolism 73 197-202.

Ren SG, Malozowski S, Sanchez P, Sweet DE, Loriaux DL \& Cassorla F 1989 Direct administration of testosterone increases rat tibial growth plate width. Acta Endocrinologica 121 401-405.

Ricciarelli E, Hernandez ER, Tedeschi C, Botero LF, Kokia E, Rohan RM, Rosenfeld RG, Albiston AL, Herington AC \& Adashi EY 1992 Rat ovarian insulin-like growth factor binding protein-3: a growth hormone dependent theca-interstitial cell-derived antigonadotropin. Endocrinology 130 3092-3094.

Rivarola MA, Phillips JA III, Migeon CJ, Heinrich JJ \& Hjelle BJ 1984 Phenotypic heterogeneity in familial isolated growth hormone deficiency type I-A. Fournal of Clinical Endocrinology and Metabolism 59 34-40.

Roberts CT Jr, Brown AL, Graham DE, Seelig S, Berry S, Gabbay KH \& Rechler MM 1986 Growth hormone regulates the abundance of insulin-like growth factor I RNA in adult rat liver. Fournal of Biological Chemistry 261 10025-10028.

Rories C \& Spelsberg TC 1989 Ovarian steroid action on gene expression: mechanisms and models. Annual Review of Physiology 51 653-681.

Sahlin L, Norstedt G \& Eriksson H 1994 Androgen regulation of the insulin-like growth factor-I and the estrogen receptor in rat uterus and liver. Fournal of Steroid Biochemistry and Molecular Biology 51 57-66.

Scow RO 1952 Effect of testosterone on muscle and other tissues and on carcass composition in hypophysectomized, thyroidectomized, and gonadectomized male rats. Endocrinology 51 42-51.

Simpson ME, Marx W, Becks H \& Evans HM 1944 Effect of testosterone propionate on the body weight and skeletal system of hypophysectomized rats. Synergism with pituitary growth hormone. Endocrinology 35 309-316.

Thompson RG, Rodriguez A, Kowarski A, Migeon CJ \& Blizzard RM 1972 Integrated concentration of growth hormone correlated with plasma testosterone and bone age in preadolescent and adolescent males. Fournal of Clinical Endocrinology and Metabolism 35 334-337.

Werner H, Woloschak M, Adamo M, Shen-Orr Z, Roberts CT Jr \& LeRoith D 1989 Developmental regulation of the rat insulin-like growth factor I receptor gene. Proceedings of the National Academy of Sciences of the USA $\mathbf{8 6}$ $7451-7455$.

Yu YM, Domene HM, Stzein J, Counts DR \& Cassorla F 1996 Developmental changes and differential regulation by testosterone and estradiol of growth hormone receptor expression in the rabbit. European Fournal of Endocrinology $135583-590$

REVISED MANUSCRIPT RECEIVED 10 May 1999 